\title{
DIURNAL AND DAILY VARIATIONS IN THE COMPOSITION OF COW FAECES
}

\author{
Majja-Liisa Salo, Ulla Peltola and Kaija Kotilainen \\ Department of Animal Husbandry, University of Helsinki
}

Received February 20, 1970

Several research workers have noted large daily and diurnal variations in the faecal excretion of $\mathrm{Cr}_{2} \mathrm{O}_{3}$ by ruminants (e.g. Brisson et al. 1957, Davis et al. 1958, Clanton 1962). The variations can be reduced to some extent by mixing chromic oxide into the feed and pelleting the feed. Still better results have been obtained by supplying $\mathrm{Cr}_{2} \mathrm{O}_{3}$ in the form of chromic oxide paper slips (Corbett et al. 1960, Troelsen 1966). However, to arrive at a reliable result, a large number of samples is required, and the chromium content should be determined from a mixture of the samples (McGuire et al. 1966). The research workers have assumed that the variations are principally due to differences in the rate of passage through the alimentary tract, the heavy and finely dispersed $\mathrm{Cr}_{2} \mathrm{O}_{3}$ traversing at a rate higher than the average rate of the feed proper. Thus JoHnson et al. (1964) noted that in sheep the rate of passage of chromic oxide was about twice as high as that of the forage. Large variations have also been observed in the faecal excretion of $\mathrm{Cr}_{2} \mathrm{O}_{3}$ by pigs (Moore 1957, Horvath et al. 1958) and by poultry (Krvimäe 1960).

On the basis of the chromic oxide values it is to be expected that variations occur also in the composition of the faeces. In respect of ruminants, this topic has been subject to surprisingly few investigations. KANE et al. (1952) noted variations in the contents of both chromic oxide and lignin. McGurre et al. (1966) compared the variations in crude protein, chromic oxide and gross energy. However, since the results are given as averages of 12 samples, the variations are naturally relatively slight.

In respect of pigs, two more comprehensive investigations have been made. Moore (1957) determined the crude protein, crude fibre, ash and chromic oxide in the faeces of pigs. Horvath et al. (1958) made analyses of the protein and ash. Both workers noted diurnal and daily variations, as well as individual variations between different animals.

The present study relates back to a digestibility trial for cows, when large daily variations were observed in the contents of both chromic oxide and the constituents of faeces proper. Several investigations have been published on the variations in the chromic oxide excretion, whereas very little is known about the variations in the faecal components, 
especially in ruminants. The objective of the present study was to clarify the magnitudes of the diurnal, daily and individual variations in the composition of cow faeces, during the indoor and pasture seasons, respectively.

\section{Experimental}

Feeding of the cows and the composition of feeds. The faeces samples were taken from dairy cows whose energy requirements were $11-14$ feed units*) per day. Cows No. 1 and 2 were pregnant, whereas cows No. 3 and 4 were not. All cows were healthy throughout the testing period. The feeding started in the morning at 5 o'clock, and in the afternoon at 3 p.m. The feeds were given in the following order:

1) Concentrate mixture, soya bean meal and molasses-beet pulp, 2) Brewers' grain, 3 ) silage, and 4) hay. On the third day of sampling (July 2), the cows were fed on pasture, and received in addition $2-4 \mathrm{~kg}$ of concentrates and $8 \mathrm{~kg}$ of Brewers' grains per day. These feeds were given at about 6 a.m. and 4 p.m.

The compositions of the concentrate mixtures were as follows:

$\begin{array}{lcc} & \begin{array}{c}\text { April 28 } \\ \text { and } \\ \text { May 12 }\end{array} & \text { July 2 } \\ \text { Oat meal } & 45 \% & \\ \text { Barley meal } & 34 \% & 47 \% \\ \text { Molasses-beet pulp } & 8 \% & 45 \% \\ \text { Milk powder } & 5 \% & \\ \text { Mineral salt mixture } & 8 \% & 8 \%\end{array}$

The hay was predominantly timothy, the pasture consisted chiefly of meadow fescue, and the silage was a calcifor-silage prepared from grasses. The dry matter content of both the silage and Brewers' grain was about $25 \%$.

Table 1. Chemical composition ( $\%$ of dry matter), and digestibility (D) of organic substances of various feeds.

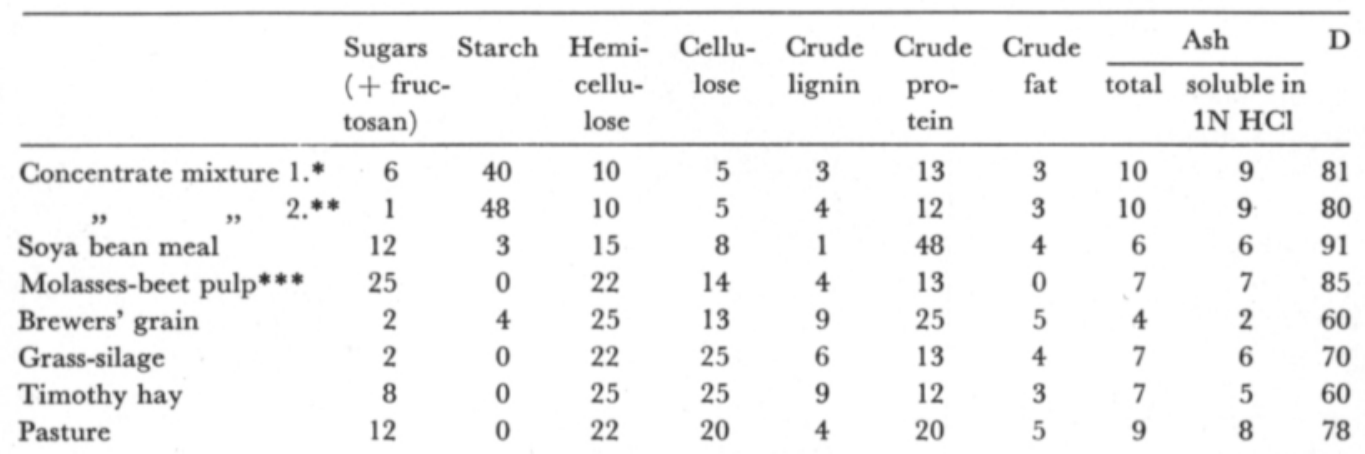

* In winter ration, ** In summer ration, *** $40 \%$ molasses.

*) 1 feed unit $=0.7$ starch units 
The compositions of various feeds are given in Table 1. Only a few feeds were analysed in this connection; the major part of the data have been estimated on the basis of analyses previously made (Salo 1965a, 1965b, 1965c, Salo \& Salmi 1968. Salo \& Kotilainen 1970). The digestibility coefficients are taken or calculated from the Tables of a textbook of animal husbandry (PALOHEIMo 1956).

Table 2 indicates the amounts of dry substances given daily to the cows. The figures relate to the tables of daily rations; the amounts consumed were not controlled closely.

The amounts of undigestible organic substances given to the cows, as calculated on the basis of the information given in Tables 1 and 2, are presented in Table 3. Data shown in Tables $1-3$ although not quite precise, facilititate the interpretation of the results.

Table 2. Amounts of dry substances given daily in various feeds, kg.

\begin{tabular}{|c|c|c|c|c|c|c|c|c|}
\hline & \multicolumn{2}{|c|}{ Cow No. 1} & \multicolumn{2}{|c|}{ Cow No. 2} & \multicolumn{2}{|c|}{ Cow No. 3} & \multicolumn{2}{|c|}{ Cow No. 4} \\
\hline & $\mathrm{A}$ and $\mathrm{B}^{*}$ & $\mathrm{C}^{*}$ & $\mathrm{~A}$ and $\mathrm{B}$ & $\mathrm{C}$ & $A$ and $B$ & $\mathrm{C}$ & $A$ and $B$ & $\mathrm{C}$ \\
\hline Concentrate mixture 1. & 4.3 & & 4.3 & & 5.1 & & 5.1 & \\
\hline , $\quad$, 2. & & 2.6 & & 1.8 & & 3.5 & & 3.5 \\
\hline Soya bean meal & 0.4 & & 0.4 & & $1.8(0.9)$ & & 1.8 & \\
\hline Molasses-beet pulp & 0.9 & & $1.7(0.9)$ & & 1.7 & & 1.7 & \\
\hline Brewer's grain & 1.7 & 1.7 & 1.7 & 1.7 & 1.7 & 1.7 & 1.7 & 1.7 \\
\hline Grass-silage & 5.3 & & 5.3 & & 5.3 & & 5.3 & \\
\hline Timothy hay & 3.5 & & 3.5 & & 2.6 & & 2.6 & \\
\hline Pasture & & $0.3 * *$ & & $9.5^{* *}$ & & $10.6^{* *}$ & & $10.6^{*}$ \\
\hline
\end{tabular}

* Date of sample collection: A = April 28, B = May 12, C = July 2.

** Calculated on the basis of milk production: 1 feed unit $=1.25 \mathrm{~kg}$ of dry matter.

Table 3. Amounts of undigestible organic substances given daily in various feeds, $\mathrm{kg}$.

\begin{tabular}{|c|c|c|c|c|c|c|c|c|}
\hline & \multicolumn{2}{|c|}{ Cow No. 1} & \multicolumn{2}{|c|}{ Cow No. 2} & \multicolumn{2}{|c|}{ Cow No. 3} & \multicolumn{2}{|c|}{ Cow No. 4} \\
\hline & $\mathrm{A}$ and $\mathrm{B}^{*}$ & $\mathrm{C}^{*}$ & $\mathrm{~A}$ and $\mathrm{B}$ & $\mathbf{C}$ & $A$ and $\mathbf{B}$ & $\mathbf{C}$ & $A$ and $B$ & $\mathrm{C}$ \\
\hline Concentrate mixture 1. & 0.7 & & 0.7 & & 0.9 & & 0.9 & \\
\hline , $\quad, \quad 2$. & & 0.5 & & 0.3 & & 0.6 & & 0.6 \\
\hline Soya bean meal & 0.03 & & 0.03 & & $0.2(0.1)$ & & 0.2 & \\
\hline Molasses-beet pulp & 0.13 & & $0.2(0.1$ & & 0.2 & & 0.2 & \\
\hline Brewers' grain & 0.6 & 0.6 & 0.6 & 0.6 & 0.6 & 0.6 & 0.6 & 0.6 \\
\hline Grass-silage & 1.5 & & 1.5 & & 1.5 & & 1.5 & \\
\hline Timothy hay & 1.3 & & 1.3 & & 1.0 & & 1.0 & \\
\hline Pasture & & 2.1 & & 1.9 & & 2.1 & & 2.1 \\
\hline
\end{tabular}

* Date of sample collection: A $=$ April 28, B $=$ May 12, C = July 2.

S a mpling, drying and grinding. The faeces samples were taken as socalled grab samples; the entire excrement was not collected. The samples amounting to $300-500 \mathrm{~g}$ were taken from the rectum at 6 and 10 a.m. and at 2, 6 and 10 p.m. Each sample was mixed well and a part of it was immediately dried in a vacuum oven at $50^{\circ} \mathrm{C}$. The dried faeces was ground in a Wiley mill using a 40-mesh screen. 
Analytical procedures. The determinations of the carbohydrates were made in accordance with the analytical scheme of SALO (1965a), although the determination of the hemicellulose content was somewhat simplified. The time-consuming determination of the uronic acids was omitted; to compensate for this, the uronic acids were not removed from the hemicellulose hydrolysate, neither was the hydrolysate purified. The absolute accuracy of the procedure was in this connection of secondary importance, since it was more important to obtain results applicable in mutual comparisons. Thus the carbohydrates and lignin were in principle determined as follows: $1 \mathrm{~g}$ of the dried sample was extracted with $80 \%$ ethanol in a Soxhlet apparatus for five hours. The dry residue was treated with $1 \mathrm{~N} \mathrm{H}_{2} \mathrm{SO}_{4}$ in a boiling-water bath, with continuous shaking for four hours. The solution was filtered and a part of the filtrate neutralised with $1 \mathrm{~N} \mathrm{NaOH}$. The reducing sugars were determined and the hemicellulose content calculated as glucosan. The insoluble residue was hydrolysed with $72 \% \mathrm{H}_{2} \mathrm{SO}_{4}$ and the cellulose content determined as reducing sugars. Crude lignin was considered to be the organic component of the hydrolysis residue. The details of the procedures are in the publication mentioned (ibid., pp. 29-34).

The crude protein was determined by the Kjeldahl method.

The total ash was determined by incineration at $700^{\circ} \mathrm{C}$. Some losses occur at this temperature; however, at a lower temperature extra work would have been required to ensure complete burning of the carbon.

The easily soluble ash was determined as follows: a $300-500 \mathrm{mg}$ sample of the total ash was treated with $200 \mathrm{ml}$ of $1 \mathrm{~N} \mathrm{HCl}$ by refluxing for 30 minutes. The resulting solution was filtered through ash-free filter paper and washed with hot water. The filter paper and the residue were incinerated at $700^{\circ} \mathrm{C}$ and the ash was weighed. The result was subtracted from the content of total ash.

\section{Results}

The results of the analyses are shown in Figs. 1 and 2, and the correlations between the different faeces components are presented in Table 5. Superficial inspection of the Figures already reveals that large daily variations occur in the composition of the cow faeces. Moreover, large diurnal variations appear during most of the days. The variations seem to be of a random nature. More regular variations might be expected during the indoor season; nevertheless, sampling at 4 hours' intervals does not reveal any trend of this kind. The results obtained during the pasture season do not significantly differ from those of the indoor season. - Any significant diurnal variations for the same cow in respect of the moisture content of the samples taken did not occur.

It is easily inferred from the figures that the irregular ash values, and particularly those relating to the sparingly soluble ash, are a factor which exercises a major influence upon the zig-zag pattern of the broken lines. However, the variations cannot be eliminated by calculating the results on the basis of the organic matter alone. The carbohydrate variations are somewhat diminished by this calculation owing to the negative correlation between the carbohydrate and ash contents. In the case of protein, the variation becomes larger because of the positive correlation between the protein and ash (Table 4).

It is noticeable already from Figs. 1 and 2 that distinct correlations prevail between certain components of the faeces.- Table 5 lists the statistically computed coefficients of 


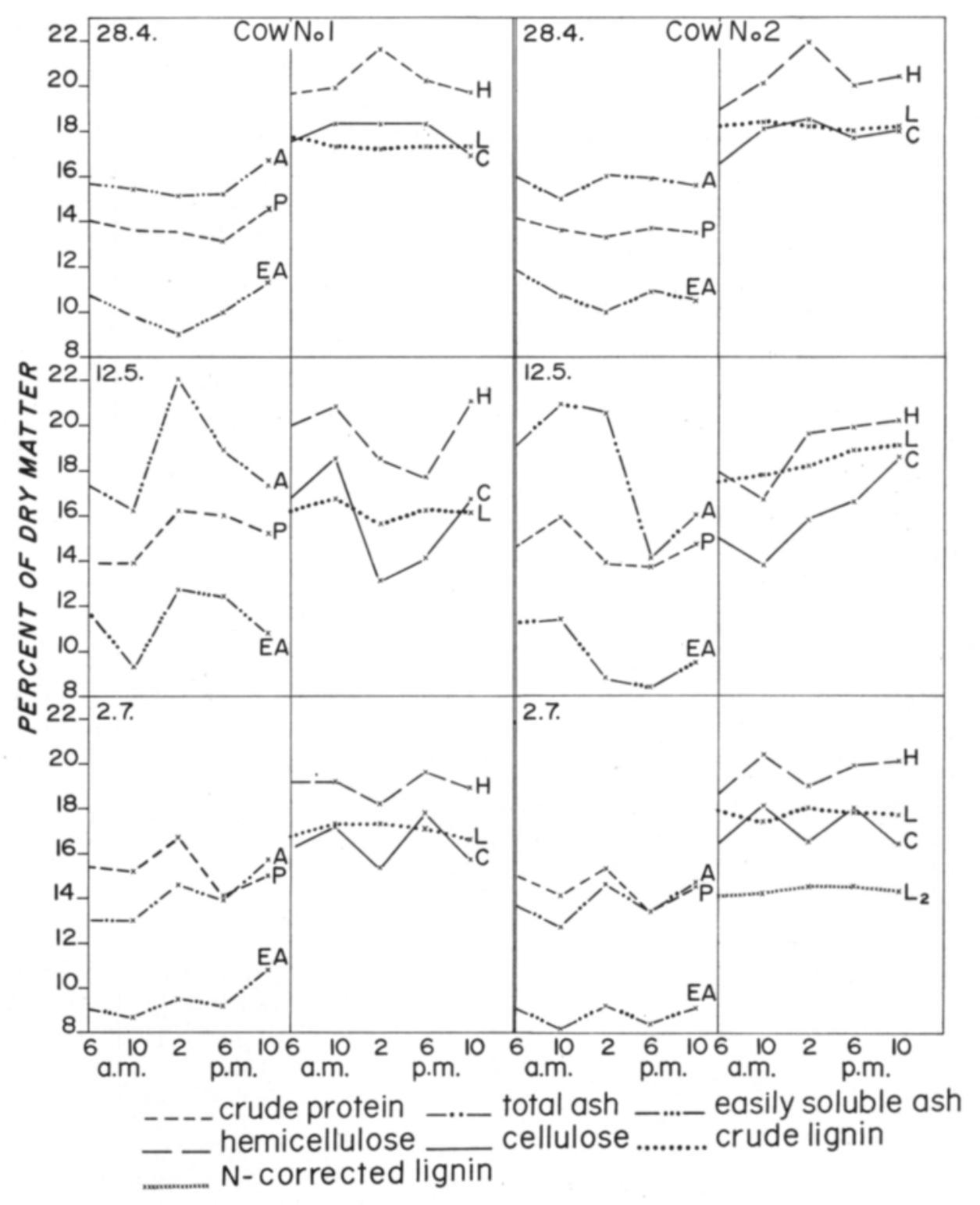

Fig. 1. Diurnal and daily variations in the composition of cow faeces.

correlation. There is a very close positive correlation between the cellulose and hemicellulose, and between the crude protein and ash. On the other hand, there is a close negative correlation between both groups of carbohydrates and the protein, carbohydrates and ash, and furthermore, between the protein and lignin contents. The correlations are closer than those noted by Moore (1957) and Horvath et al. (1958) for pig faeces. The crude lignin is least of all correlated to the other components. This fact will be reverted to later in the discussion. 


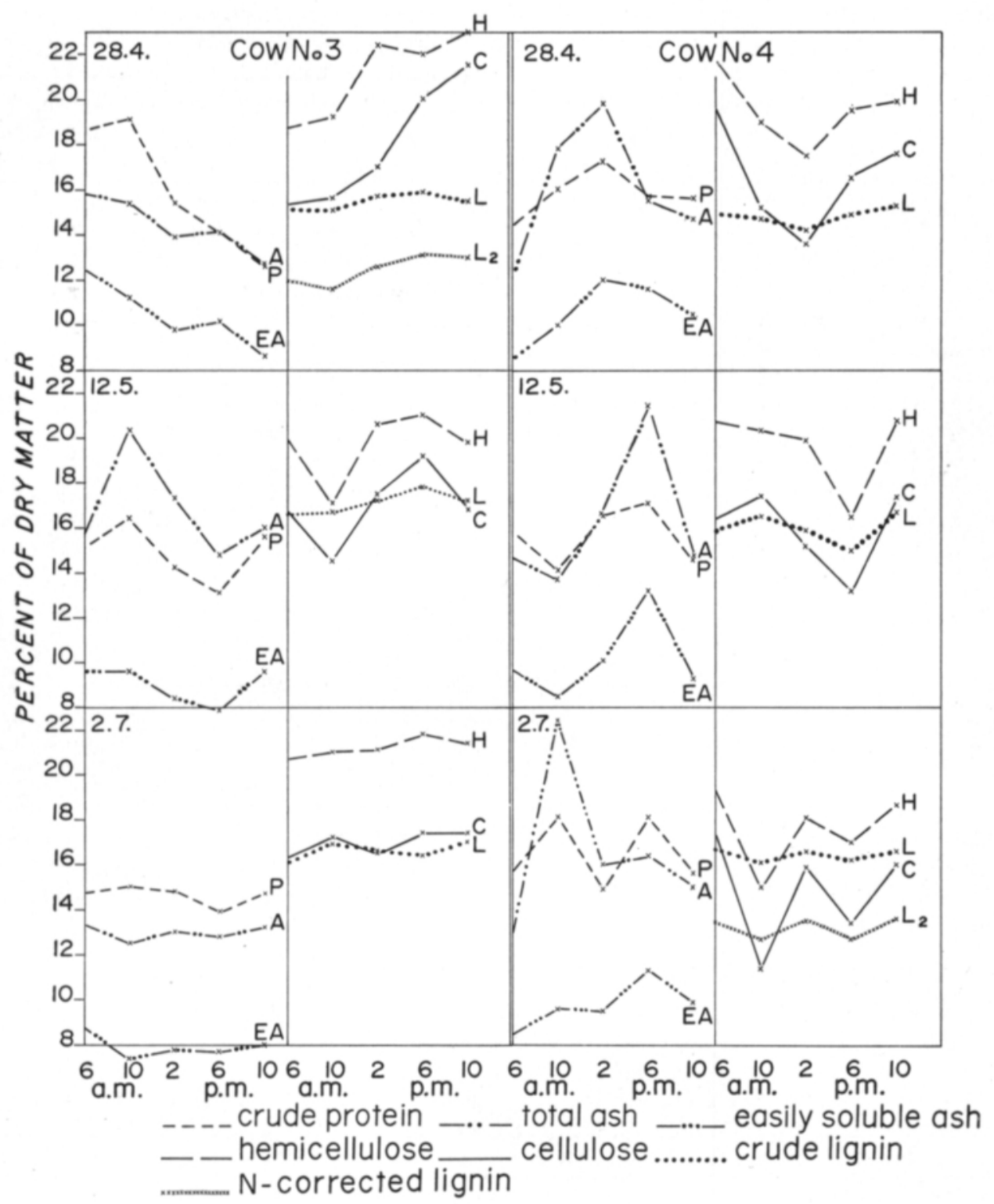

Fig. 2. Diurnal and daily variations in the composition of cow faeces.

\section{Discussion}

The influence of the variations upon the digestibility c o efficien ts. When the results are inspected from the viewpoint of the digestibility tests, it immediately becomes evident that the grab sampling technique is unreliable. As already mentioned in the introduction, the chromic oxide variation has been proved in several connections, whereas almost no attention has been paid to the variations occurring 
Table 4. Examples of the diurnal variations in the faecal composition as percentages of a) dry matter, b) dry matter free from sparingly soluble ash, c) organic matter.

\begin{tabular}{|c|c|c|c|c|c|c|c|c|c|c|c|c|c|c|c|}
\hline \multirow[t]{2}{*}{ Cow } & \multirow[t]{2}{*}{ No. 4} & \multicolumn{3}{|c|}{ Hemicellulose } & \multicolumn{3}{|c|}{ Cellulose } & \multicolumn{3}{|c|}{ Crude lignin } & \multicolumn{3}{|c|}{ Crude protein } & \multirow{2}{*}{\multicolumn{2}{|c|}{$\begin{array}{r}\text { Ash (a) } \\
\text { total soluble in } \\
\text { N } 1 \mathrm{HCl}\end{array}$}} \\
\hline & & a & b & c & a & b & c & a & b & c & a & $\mathbf{b}$ & c & & \\
\hline \multirow[t]{5}{*}{ May 12} & 6 a.m. & 20.7 & 21.8 & 24.2 & 16.4 & 17.3 & 19.2 & 15.9 & 16.7 & 18.6 & 15.8 & 16.6 & 18.5 & 14.6 & 9.6 \\
\hline & 10, & 20.3 & 21.4 & 23.5 & 17.4 & 18.4 & 20.2 & 16.5 & 17.4 & 19.1 & 14.1 & 14.9 & 16.3 & 13.7 & 8.5 \\
\hline & 2 p.m. & 19.9 & 21.3 & 23.9 & 15.2 & 16.3 & 18.2 & 15.9 & 17.0 & 19.1 & 16.6 & 17.8 & 19.9 & 16.6 & 10.1 \\
\hline & 6, & 16.5 & 18.0 & 21.0 & 13.2 & 14.4 & 16.8 & 15.0 & 16.3 & 19.1 & 17.1 & 18.6 & 21.8 & 21.4 & 13.2 \\
\hline & 10 & 20.8 & 22.0 & 24.4 & 17.4 & 18.4 & 20.4 & 16.7 & 17.7 & 19.6 & 14.6 & 15.4 & 17.1 & 14.7 & 9.3 \\
\hline \multicolumn{2}{|c|}{ Average } & 19.6 & 20.9 & 23.4 & 15.9 & 17.0 & 19.0 & 16.0 & 17.0 & 19.1 & 15.6 & 16.7 & 18.7 & - & - \\
\hline \multirow[t]{5}{*}{ July 2} & 6 a.m. & 19.3 & 20.2 & 22.2 & 17.3 & 18.1 & 19.9 & 16.7 & 17.5 & 19.2 & 15.7 & 16.4 & 18.0 & 12.9 & 8.5 \\
\hline & $10 \%$ & 15.0 & 17.2 & 19.3 & 11.4 & 13.1 & 14.7 & 16.1 & 18.5 & 20.7 & 18.1 & 20.8 & 23.3 & 22.4 & 9.6 \\
\hline & 2 p.m. & 18.1 & 19.4 & 21.5 & 15.9 & 17.0 & 18.9 & 16.6 & 17.8 & 19.8 & 14.9 & 15.9 & 17.7 & 16.0 & 9.5 \\
\hline & 6, & 17.0 & 17.9 & 20.3 & 13.4 & 14.1 & 16.0 & 16.2 & 17.1 & 19.4 & 18.1 & 19.1 & 21.7 & 16.4 & 11.3 \\
\hline & 10 & 18.7 & 19.7 & 22.0 & 16.0 & 16.9 & 18.8 & 16.6 & 17.5 & 19.5 & 15.6 & 16.4 & 18.4 & 15.0 & 9.9 \\
\hline \multicolumn{2}{|c|}{ Average } & 17.6 & 18.9 & 21.1 & 14.8 & 15.8 & 17.7 & 16.4 & 17.7 & 19.7 & 16.5 & 17.7 & 19.8 & - & - \\
\hline
\end{tabular}

Table 5. Coefficients of correlation between different components of cow faeces.

\begin{tabular}{llcccc}
\hline & $\begin{array}{c}\text { Ash soluble } \\
\text { in 1N HCl }\end{array}$ & $\begin{array}{c}\text { Crude } \\
\text { protein }\end{array}$ & $\begin{array}{c}\text { Hemi- } \\
\text { cellulose }\end{array}$ & Cellulose & Crude lignin \\
\hline Total ash & $+0.6316 * * *$ & $+0.3986 * * *$ & $-0.6735 * * *$ & $-0.7092^{* * *}$ & -0.1400 \\
Ash soluble in 1N HCl & & $+0.4379 * * *$ & $-0.5102^{* * *}$ & $-0.5052^{* * *}$ & $-0.3168 * *$ \\
Crude protein & & & $-0.5317 * * *$ & $-0.7626 * * *$ & $-0.5174 * * *$ \\
Hemicellulose & & & & $+0.8512 * * *$ & +0.0904 \\
Cellulose & & & & $+0.2820^{*}$
\end{tabular}

$*=\mathrm{P}<0.05,{ }^{* *}=\mathrm{P}<0.01,{ }^{* * *}=\mathrm{P}<0.001$

Table 6. Examples of digestibility coefficients as calculated on the composition of different diurnal samples.

\begin{tabular}{|c|c|c|c|c|}
\hline & & Hemicellulose & Cellulose & Crude protein \\
\hline \multirow[t]{5}{*}{ Cow No. 3, April 28} & 6 a.m. & 65.6 & 66.2 & 63.2 \\
\hline & 10, & 64.6 & 65.6 & 62.2 \\
\hline & 2 p.m. & 60.4 & 63.9 & 70.7 \\
\hline & 6, & 61.5 & 58.1 & 74.5 \\
\hline & 10, & 58.7 & 53.8 & 75.7 \\
\hline Average & & $62.2 \pm 1.3$ & $61.5 \pm 2.4$ & $69.3 \pm 2.8$ \\
\hline \multirow[t]{5}{*}{ Cow No. 4, April 28} & 6 a.m. & 59.7 & 56.4 & 71.1 \\
\hline & 10, & 64.1 & 65.5 & 67.5 \\
\hline & 2 p.m. & 65.8 & 68.1 & 63.8 \\
\hline & 6, & 63.6 & 62.9 & 68.5 \\
\hline & 10, & 63.8 & 61.7 & 69.5 \\
\hline Average & & $63.4 \pm 1.0$ & $62.9 \pm 2.0$ & $68.1 \pm 1.2$ \\
\hline
\end{tabular}


in the composition of the faeces proper. Table 6 provides examples of the digestibility coefficients for the cows No. 3 and 4, as calculated on the basis of the various samples taken on April 28, 1969. The average feed composition has been calculated on the basis of the information given in Tables 1 and 2. The percentages reported are thus not entirely exact, but they are sufficient for relative comparisons. In these computations, the crude lignin has been used as a tracer.

It can be seen from Table 6 that the diurnal variation of the digestibility of crude protein and cellulose is larger than that of the hemicellulose; in the examples given the maximum variation amounts to $12-13$ percentage-units. The directions of the variations are the opposite, since a close negative correlation exists between the protein and cellulose contents. The negative correlation between the protein and the crude lignin - the indicator - still augments the variation of the digestibility of protein. As regards cellulose, there is a positive although weak correlation, which tends to reduce the variation. The reasons for the large variations in opposite directions in the contents of cellulose and protein will be discussed later.

In comparison with the usual digestibility trials it is obvious that the present investigation is exaggerated in two respects: there are too many different feeds and the levels of feed intake are large. In the digestibility trials there are generally only one or two kinds of feeds, and the level of rations corresponds to the maintenance requirement. It can therefore be presumed that the variations noted in the composition of the faeces are larger than those prevailing in normal conditions of digestibility trials. On the other hand, the scanty information available in the literature on the variations in the composition of faeces is in agreement with the results of the present investigation. KANE et al. (1952) noted that the lignin content of cow faeces varied within the limits of approximately 2 percent units; in the present study, the crude lignin — the only evenly occurring component — varies within a somewhat narrower range. In Moore's experiments (1957), the pigs received homogenous feed, nevertheless the composition of the faeces varied considerably. Moore noted that the protein and crude fibre were inversely related, a similar effect can be noted in the present study in respect of the relationships between the protein and cellulose, and the protein and hemicellulose, respectively. On the basis of his results Moore (1958) proposed that a simple collection method, consisting of taking at random samples amounting to $10-20 \%$ of the total faecal production, gave reliable results for the digestibility coefincients of crude protein, dry matter and $\mathrm{Cr}_{2} \mathrm{O}_{3}$-free ash. However, for the determination of the digestibility of the crude fibre, the collection of some 80 $90 \%$ of the total faeces passed was necessary.

From the results it is furthermore observable that the diurnal variations in the crude lignin content of cow faeces are surprisingly small, despite the very heterogenous composition of this component (cf. SALo 1965a, pp. 61-70). Therefore, the crude lignin seems to be of some value as a tracer. In this connection nothing can be gained by the application of a protein correction $(6.25 \times \mathrm{N})$ for lignin; it merely more than doubles the analytical effort.

Implications in respect of the digestive physiology of the ruminant. The analytical data obtained give intimations also as regards the general course of the ruminant's digestion. The ingested feed is rapidly mixed with the previous contents of rumen (SMrT et al. 1956). However, the ingesta does not proceed 
from the reticulo-rumen in a homogenous condition, but some kind of sorting is carried out in the rumen. LENKEIT (1933) and BALCH (1950) found that finely ground food remains a shorter time in the reticulo-rumen than food in a coarser form. SмrтH et al. (1956), who experimented with fistulated steers, observed that hay and grain particles follow distinctly different paths in traversing the rumen. The coarse hay particles collect in a mmat» in the top part of the rumen and remain there for many hours. In contrast, the grain particles are initially mixed throughout the rumen ingesta, but settle rapidly to the floor of the rumen and reticulum and then pass to the omasum. Also Blaxter (1955) has noted that ground hay passes through the alimentary canal of sheep about twice as fast as does long hay, and is digested at lower efficiency. The quantity of feed is also of importance: a large amount of fodder, particularly if it is ground, traverses much faster the alimentary canal and is more poorly digested than a smaller quantity of the same fodder (ibid.). In a previous work (SALo 1958), an observation was made to the effect that some fractiation occurs in the rumen also on purely hay diet: the leafy material leaves the rumen faster than do the stems. The analyses made on the digesta indicated that four hours after the feeding the methoxyl content of the lignin had increased in the rumen ingesta, whereas it had diminished in other parts of the alimentary tract. The methoxyl content of the lignin in leaves is much lower than that in the stems (SALO 1957).

In the present investigation the cows received during the indoor-season a ration of roughage-concentrate corresponding to $6-7$ feed units per meal. The rate of passage was therefore high and the digestibility poorer than the average. On the basis of the faecesanalyses and the literature cited above, the following conclusions can be drawn in respect of the progress of the digestion: Shortly after the feeding, the heavier and more finely ground material pass from the reticulo-rumen further into the alimentary canal. This fraction is made up of concentrate, and to some extent also of the easily disintegrated leaf material. In comparison with the material left behind in the rumen it is rich in starch, protein and ash. KARR et al. (1966) have pointed out that with a high-grain intake, considerable quantities of starch may pass from the rumen undigested. A part of the starch is then carried into the posterior ileum (LrTtLe et al. 1968) and obviously further into the large intestines, where together with the protein it offers fertile growth conditions for the bacteria. In fact, the faeces samples rich in protein and ash but poor in cellulose indicate a high content of bacteria (SALo 1965a, p. 61). On the other hand, the samples which in contrast are rich in carbohydrates but poor in protein indicate feed residues abundant in roughage material. It may seem that the uniform content of crude lignin contradicts this periodical theory. However, this is not the case. As has been demonstrated in a previous investigation (ibid.), approximately the same amounts of »lignin» are obtained by the conventional lignin determination method for both the bacteria in cow faeces and the undigested feed residue. The relatively high content of true lignin in the samples rich. in carbohydrates, and the relatively high content of pseudolignin in bacteria-rich samples thus compensate each other. Three examples of the protein-corrected lignin contents (crude lignin minus $6.25 \times \mathrm{N}$ ) are also shown in Figures 1 and 2; it is noticeable that large differences do not occur in the nitrogen content of the crude lignin. As could be expected, the crude lignin obtained from the samples rich in protein exhibited a somewhat higher content of nitrogen.

Another explanation for the variations in the composition of the faeces might be a 
slower rate of passage of the feed in the digestive tract during the night, resulting in a more complete digestion in the large intestines and possibly also in the reticulo-rumen. However, the variation in the cellulose content is too high to be explicable on this basis alone. At most, this possibility is acceptable as a supplement to the theory presented above. Moore (1957) and Horvath et al. (1958) have suggested that the possible reasons for the diurnal variation in the swine faeces would lie in the differences in the time of digestion in the lower alimentary tract and/or differences in the rate of passage of various feed fractions through the stomach.

A striking feature in Figs. 1 and 2 is the ash peak occurring on several days, attributable to the sparingly soluble ash. The author has previously analysed the contents of the alimentary tract of the cows (PALOHEImo et al. 1955, MÄKelÄ 1956) and noted that the sand present in the fodder collects in the abomasum. The analytical data of the present investigation indicate that occasionally an abnormally large dose of sand moves off. The large dose of sand always coincides with the fraction rich in protein but poor in cellulose. A high ash peak of this type was noted also during the pasture season for one of the cows. Samples abundant in sand were not encountered on all the days of the testing, possibly on account of the samples taken representing only 5-10 per cent of the total faecal excretion. In addition to the sand, the sparingly soluble ash fraction also contains the silicates present in the feeds. The amounts are, however, relatively small as is seen from Table 1.

\section{$S u m$ mary}

The work is concerned with the diurnal and daily variations in the composition of cow faeces. Samples were taken from four dairy cows five times a day during the course of three days. The cows were fed on roughage and concentrates. The faecal samples were analysed for hemicellulose, cellulose, lignin, crude protein, total ash and the ash soluble in $1 \mathrm{~N} \mathrm{HCl}$. The following results were noted:

Large variations occur in the composition of cow faeces. The largest variations relate to the cellulose, crude protein and total ash, whereas the content of lignin varies only little. Diurnal regularity was not noted.

A close positive correlation was noted between the contents of hemicellulose and cellulose, as well as between the crude protein and the ash contents. A close negative correlation existed between both groups of carbohydrates and the crude protein, both carbohydrate groups and the ash, and between the crude protein and crude lignin.

A high ash peak, attributable to sparingly soluble ash, was noted on several days. These ash-rich samples always have a high content of crude protein but a low content of carbohydrates.

The digestibilities of the cellulose and crude protein were inversely related and varied during the same day of sampling within a range of as much as $12-13$ percent units.

The digestibility and rate of feed passage cannot be reliably evaluated by a grab sampling technique, at least not in instances when the cows are receiving both roughage and concentrates.

As a possible reason for the variations it is suggested that the feed leaves the reticulorumen as different fractions. Shortly after the feeding, the material rich in concentrate moves on, whereas later mainly roughage material passes further into the alimentary 
tract. In the large intestines the former fraction results in a more intensive growth of bacteria, and the faeces originating from it contains a relatively higher proportion of bacterial matter.

\section{REFERENCES}

BALCH, C. C. 1950. Factors affecting the utilization of food by dairy cows. I. The rate of passage of food through the digestive tract. Brit. J. Nutr. 4: 361-388.

Brisson, G. J., Pigden, W. J. \& Sylvestre, P. E. 1957. Effect of frequence of administration of chromic oxide on its fecal excretion pattern by grazing cattle. Can. J. Anim. Sci. 37: 90-94.

Clanton, D. C. 1962. Variation in chromic oxide methods of determining digestibility of hand-fed beef cattle rations. J. Anim. Sci. 21: 214-218.

Corbett, J. L., Greenhalgh, J. F. D., McDonald, I. \& Florence, E. 1960. Excretion of chromium sesquioxide administrated as a component of paper to sheep. Brit. J. Nutr. 14: 289-299.

Davis, C. L., Byers, J. H. \& LuBer. L. E. 1958. An evaluation of the chromic oxide method for determining digestibility. J. Dairy Sci. 41: 152-159.

Horvath, D. J., Peterson, A. J., Clawson, B. E., Sheffy, B. E. \& Loosly, J. K. 1958. Diurnal variations in the composition of swine feces. J. Anim. Sci. 17: 869-874.

Johnson, D. E., Dinusson, W. E. \& Bolin, D. W. 1964. Rate of passage of chromic oxide and composition of digesta along alimentary tract of whethers. Ibid. 23: 499-505.

KANe, E. A., JAcobson, W. C. \& Moore, L. A. 1952. Diurnal variation in the excretion of chromium oxide and lignin. J. Nutr. 47: 263-273.

KarR, M. R., Little, C. O. \& Mrtchell, Jr. G. E. 1966. Starch disappearance from different segments of the digestive tract of steers. J. Anim. Sci. 25: 652-654.

Krvimäz, A. 1960. Diurnal variation of chromic oxide excretion in poultry feces. Kungl. Lantbrukshögskolans Ann. 26: 121-133.

Lenkert, W. 1933. Neuere Ergebnisse der Vergleichenden Physiologie der Verdauung der Säugetiere. Ergebn. Physiol. Expl. Pharmakol. 35: 573-631.

Little, C. O., Mrtchell, G. E. \& Reitnour, C. M. 1968. Postruminal digestion of corn starch in steers. J. Anim. Sci. 27: 790-792.

McGuire, R. L., Bradley, N. W. \& LitTle, C. O. 1966. Effects of frequency of feeding on excretion of chromic oxide, crude protein and gross energy and on nutrient digestibility by steers. Ibid. 25: 185-191.

Moore, J. H. 1957. Diurnal variations in the composition of the faeces of pigs on diets containing chromium oxide. Brit. J. Nutr. 11: 273-288.

- - 1958. The effect of diurnal variations in composition of the faeces of pigs on the determination of digestibility coefficients by the chromium-oxide method. Ibid. 12: 24-34.

MÄKELẌ, A. 1956. Studies on the questions of bulk in the nutrition of farm animals with special reference to cattle. Acta Agr. Fenn. 85: 1-130.

PALонEтмо, L. 1956. Kotieläinhoidon perusteita. 619 p. Jyväskylä.

- - MÄKELẌ, A. \& SALO, M-L. 1955. Some quantitative data on the role of the ruminant proventriculi in the digestion and absorption of nitrogen-free organic matter. J. Sci. Agric. Soc. Finl. 27: 70-76.

SALo, M-L. 1957. Lignin studies. II. The lignin content and properties of lignin in different materials. Ibid. 29: 202-210.

—— 1958. Lignin studies. III. Lignin as a tracer in digestibility investigations. Ibid. 30: 97-104.

- - 1965a. Determination of carbohydrate fractions in animal food and faeces. Acta Agr. Fenn. 105: $1-102$.

-»-1965b. On the content of cell-wall constituents in various plant materials. J. Sci. Agric. Soc. Finl. 37: $127-134$.

-» - 1965c. The composition of pasture grasses at the University Farm Viik. Ibid. 37: 135-147.

—)— \& SALMI, M. 1968. Determination of starch by the amyloglucosidase method. Ibid. 40: 38-45.

—»— \& Kotilainen, K. 1970. On the carbohydrate composition and nutritive value of some cereals. Ibid. 42: 21-29. 
Smith, P. H., Sweeney, H. C., Rooney, J. R., King, K. W. \& Moore, W. E. C. 1956. Stratifications and kinetic changes in the ingesta of the bovine rumen. J. Dairy Sci. 39: 598-609.

Troelsen, J. E. 1966. Pelleting of chromic oxide paper for administration to cattle and sheep. Can. J. Anim. Sci. 46: 226-227.

\title{
SELOSTUS
}

\section{LEHMÄNSONNAN KOOSTUMUKSESSA VUOROKAUDEN AIKANA ESIINTYVISTÄ VAIHTELUISTA}

\author{
Maija-Linsa Salo, Ulela Peltola ja Kaija Kotilainen
}

\section{Kotieläintieteen laitos, Helsingin yliopisto}

Tutkimus käsitteli lehmänsonnan koostumuksessa esiintyvää vaihtelua. Näytteitä otettiin neljältä lehmältä viisi kertaa päivässä kolmena päivänä. Lehmät saivat korsi- ja väkirehua. Sonnasta määritettiin hemiselluloosa, selluloosa, ligniini, raakaproteiini, kokonaistuhka ja $1 \mathrm{~N} \mathrm{HCl}$-liukoinen tuhka. Tutkimuksessa tehtiin seuraavat havainnot:

- Lehmänsonnan koostumuksessa esiintyy suuria vaihteluita. Eniten vaihtelevat selluloosa, raakaproteiini ja kokonaistuhka, vähiten raakaligniini. Vuorokauden aikaan liittyvää säännönmukaisuutta ei todettu.

— Kiinteä positiivinen vuorosuhde todettiin hemiselluloosan ja selluloosan, sekä raakaproteiinin ja tuhkan välillä. Kiinteä negatiivinen vuorosuhde vallitsi molempien hiilihydraattiryhmien ja raakaproteiinin, hiilihydraattiryhmien ja tuhkan sekä raakaproteiinin ja raakaligniinin välillä.

— Useille päiville osui näyte, joka sisälsi runsaasti hiekkaa. Tämä ylisuuri hiekka-annos esiintyi aina proteiinirikkaassa, hiilihydraattiköyhässä uloste-erässä.

— Saman päivän eri näytteistä laskettuna vaihtelivat selluloosan ja raakaproteiinin sulavuudet — vastakkaisina - jopa $12-13 \%$-yksikön rajoissa.

- Sonnan kerääminen satunnaisnäytteinä ei anna luotettavaa tulosta sulavuutta ja ruoan kulkua koskevissa tutkimuksissa, ei ainakaan silloin kun lehmät saavat sekä korsi- että väkirehua.

— Vaihteluiden pääasialliseksi syyksi on arveltu sitä, että rehu lähtee pötsi-verkkomahasta erilaisina fraktioina. Pian ruokinnan jälkeen lähtee voittopuolisesti hienojakoista, väkirehuvaltaista ainesta, myöhemmin voittopuolisesti korsiainesta. Edellinen fraktio saa paksusuolessa aikaan voimakkaamman bakteerien kasvun kuin jälkimmäinen ja siitä peräisin oleva sonta sisältää suhteellisesti enemmän bakteeriainesta. 